\title{
Epoxidation of 1-buten-3-ol under atmospheric pressure over the Ti-Beta catalyst
}

\author{
Agnieszka Wróblewska, Joanna Wajzberg \\ Institute of Organic Chemical Technology, Szczecin University of Technology, ul. Pułaskiego 10, 70-322 Szczecin, Poland, \\ e-mail: Agnieszka.Wroblewska@ps.pl
}

\begin{abstract}
The results of 1-buten-3-ol (1B3O) epoxidation with $30 \%$ hydrogen peroxide over the Ti-Beta catalyst were presented. The studies were performed under the atmospheric pressure and at the presence of methanol as a solvent. There was examined the influence of the following parameters: the temperature $\left(0-60^{\circ} \mathrm{C}\right)$, the molar ratio of $1 \mathrm{~B} 3 \mathrm{O} / \mathrm{H}_{2} \mathrm{O}_{2}(1: 1-5: 1)$, methanol concentration $(5-90 \mathrm{wt} \%)$, the Ti-Beta catalyst concentration $(0.1-5.0 \mathrm{wt} \%)$ and the reaction time $(0.5-5.0 \mathrm{~h})$. The optimal parameters were determined by using the following functions: the selectivity of the transformation to 1,2-epoxy-3-butanol $(1,2 \mathrm{E} 3 \mathrm{~B})$ in relation to $1 \mathrm{~B} 3 \mathrm{O}$ consumed, the selectivity of the transformation to organic compounds in relation to hydrogen peroxide consumed, the conversions of $1 \mathrm{~B} 3 \mathrm{O}$ and hydrogen peroxide. The main product of epoxidation was 1,2-epoxy-3-butanol, epoxide having several applications.
\end{abstract}

Keywords: liquid phase epoxidation, 1,2-epoxy-3-butanol, Ti-Beta catalyst.

Presented at VII Conference Wasteless Technologies and Waste Management in Chemical Industry and Agriculture, Międzyzdroje, 12 - 15 June, 2007.

\section{INTRODUCTION}

Hydrogen peroxide is a very interesting oxidizing agent in an organic synthesis ${ }^{1}$. Mainly, because it is cheap and easily received. The product of its decomposition is water, so all the processes using hydrogen peroxide are more ecologically safe (they generate less amount of waste). One of the processes, where the hydrogen peroxide found an application, is epoxidation of olefins to olefin oxides (epoxides). It can be performed by using titanium-silicalite zeolites as catalysts. An important advantage of this catalysts is the ease of their regeneration and quite big stability when the proper conditions of reaction are followed ${ }^{2}$. The Ti-Beta catalyst is a member of the titanium silicalite catalysts family. Apart from silicon atoms, oxygen and titanium, it contains in its structure aluminium atoms ${ }^{2}$. It causes a formation of additional negative charges in the zeolite structure. Titanium and aluminium take the main part in the stabilization of the zeolite Ti-Beta structure. The presence of aluminium makes Brfnsted acidity and decides about the hydrophilic chemical character of the catalyst $^{3}$. The Ti-Beta zeolite crystallizes in the tetragonal system, the size of the channels is $0,74 \mathrm{~nm}$, and the entrance holes into the channels are limited by twelve edges. It is synthesized during hydrothermal crystallization in the presence of tetraethyloammonium hydroxide as a clatrating compound ${ }^{3}$.

The epoxidation of 1-butene-3-ol with $30 \%$ hydrogen peroxide over the Ti-Beta catalyst leads to the formation of 1,2-epoxy-3-butanol (1,2E3B). This compound has various applications. It belongs to the optically active compounds. (2S,3R)-1,2-Epoxy-3-butanol is used in the synthesis of drugs: Epothilone $\mathrm{B}^{4}$ and $\mathrm{A}^{5}$. Epothilone $\mathrm{B}$ is macrolide which was isolated from bacterial culture Sorangium Cellulosum and is currently in clinical studies. It blocks the division of cancer cells and is more efficient in this action than taxol' ${ }^{6}$ 1,2-Epoxy-3-butanol was also applied in the synthesis of (-)-rhodinose, a sugar component of such antibiotics as rhodomycine and streptolydigine ${ }^{7}$. Streptolydigine is an antibiotic that impedes RNA polymerase (enzyme forming the RNA molecule on the matrix of one DNA chain). The studies of 1B30 epoxidation was undertaken to find such technological conditions of the process performing, in which $1,2 \mathrm{E} 3 \mathrm{~B}$ is formed: with the highest selectivity and at the same time a high conversion of $1 \mathrm{~B} 30$ and the selectivity of transformation to organic compounds in relation to $1 \mathrm{~B} 30$ reacted.

\section{EXPERIMENTAL}

In the process of 1-buten-3-ol epoxidation there were used: 1-buten-3-ol (1B3O) (97\%, Fluka), hydrogen peroxide (30-proc. water solution, POCh Gliwice), methanol (POCh Gliwice), the Ti-Beta catalyst (prepared in the Institute of Organic Chemical Technology). The Ti-Beta catalyst was prepared using the method described by Camblor at al. ${ }^{\mathbf{8}}$ The epoxidation was performed under the atmospheric pressure in the three-necked flask fitted with a reflux condenser, thermometer and the dropping funnel. The reactants were introduced in the following order: catalyst, 1B3O and methanol (solvent). Hydrogen peroxide was dropped at the reaction temperature while mixing intensively. Mixing was performed with a magnetic stirrer. The Products were examined quantitatively using a gas chromatography. The chromatographic analysis was performed on the Focus apparatus with the flame ionization detector (FID), fitted with the Quadrex capillary column $(30 \mathrm{~m} \times 250 \mu \mathrm{m} \times 0,25 \mu \mathrm{m})$. The parameters of the chromatographic separation were as follows: the pressure of helium $35 \mathrm{kPa}$, the detector temperature $250^{\circ} \mathrm{C}$, the temperature of the samples' chamber $150^{\circ} \mathrm{C}$. The temperature of the thermostat increased as follows : isothermally at $40^{\circ} \mathrm{C}$ for 3 minutes, followed by an increase of the temperature at the rate of $10^{\circ} \mathrm{C} /$ minute, isothermally at $250^{\circ} \mathrm{C}$ for 5 minutes and cooling to $40^{\circ} \mathrm{C}$. Hydrogen peroxide consumption was determined iodometrically? 


\section{RESULTS}

Epoxidation of $1 \mathrm{~B} 3 \mathrm{O}$ with $30 \%$ hydrogen peroxide over Ti-Beta catalyst leads to 1,2-epoxy-3-butanol as a main product:

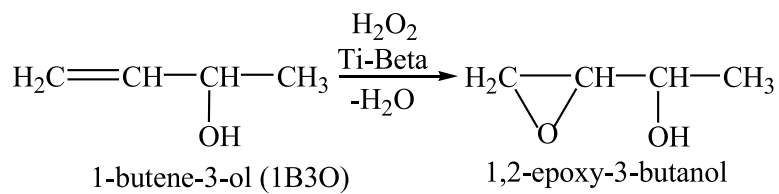

$1,2 \mathrm{E} 3 \mathrm{~B}$ is sensitive to an attack of a nucleophilic compound (especially water and methanol), which are present in the reaction medium. As a result of it a break of an epoxide ring takes place and 1,2,3-butanetriol and 1,2,3trimethoxybutane are formed.<smiles>CC(O)C(O)C(O)C(O)C(O)CO</smiles>

$$
\stackrel{\mathrm{CH}_{2}-\mathrm{CH}-\mathrm{CH}-\mathrm{CH}_{3}}{|+|}
$$

1,2,3-trimethoxybutane

Scheme 1. The products of 2-butene-1-ol epoxidation

Depending on the process parameters there can be received some etheric products such as: 3-(3-methyl-1-propene)-3-methyl-1,2-epoxypropane ether, bis(3-methyl-1propene) ether, 4-(1-methyl-2-propene)-butane-2,3-diol ether, bis(3-methyl-1,2-epoxypropane) ether, bis(2,3dihydroxybutane) ether, 3-(2,3-dihydroxybutane)-3-methyl1,2-epoxypropane ether. Using the proper parameters of the process their formation can be eliminated.

In the studies of the influence of temperature on the course of epoxidation process there were taken the following starting conditions: the molar ratio of $1 \mathrm{~B} 3 \mathrm{O} /$ $\mathrm{H}_{2} \mathrm{O}_{2}=1: 1$, solvent concentration (methanol) $40 \mathrm{wt} \%$, catalyst concentration $3 \mathrm{wt} \%$ and the time reaction time $3 \mathrm{~h}$. Taking an analysis the influence of temperature on the selectivity of transformation to 1,2-epoxy-3-butanol in relation to $1 \mathrm{~B} 3 \mathrm{O}$ consumed (Figure 1a) it was found that an increase in temperature from 0 to $20^{\circ} \mathrm{C}$ leads to a rise in the value of the function from $0.0 \mathrm{~mol} \%$ to $34.1 \mathrm{~mol} \%$. The further increase in temperature to $60^{\circ} \mathrm{C}$ causes only a slight decrease in the value of the function to 22.1 mol\%. It is caused by the increase in the speed of hydration of 1,2-epoxy-3-butanol to 1,2,3-butanetriol as well as the formation of 1,2-epoxy-3-methoxybutane. The conversion of $1 \mathrm{~B} 3 \mathrm{O}$ increases with the increases of the temperature from $0.0 \mathrm{~mol} \%\left(0^{\circ} \mathrm{C}\right)$ to $83.9 \mathrm{~mol} \%\left(20^{\circ} \mathrm{C}\right)$. The further increase in temperature does not make the other important changes of the value of the function. The selectivity of the transformation to organic compounds in relation to $\mathrm{H}_{2} \mathrm{O}_{2}$ consumed changes in the similar way. The conversion of $\mathrm{H}_{2} \mathrm{O}_{2}$ is constant in the range of the investigated temperatures and is about $97.0 \mathrm{~mol} \%$. On the basis of the studies the optimum temperature was taken as $20^{\circ} \mathrm{C}$.

The influence of the molar ratio of $1 \mathrm{~B} 3 \mathrm{O} / \mathrm{H}_{2} \mathrm{O}_{2}$ was examined in the range of $0.5: 1-5: 1$. The syntheses were performed at the temperature of $20^{\circ} \mathrm{C}$, the other param- a)

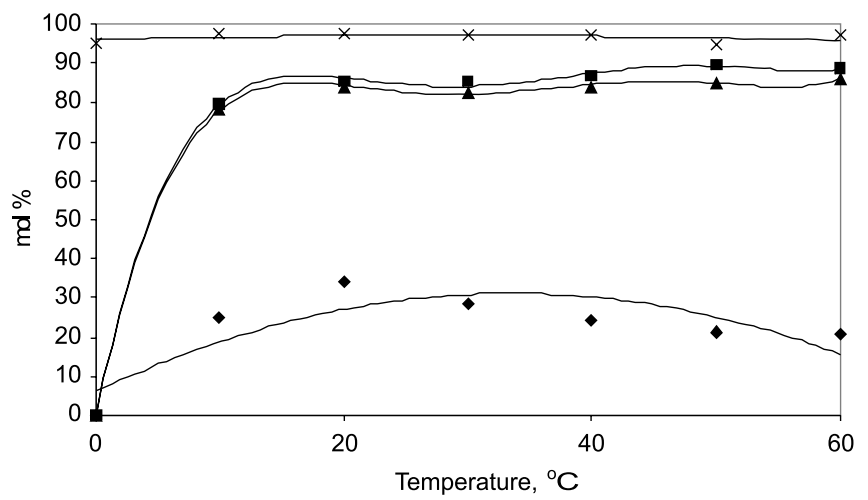

b)

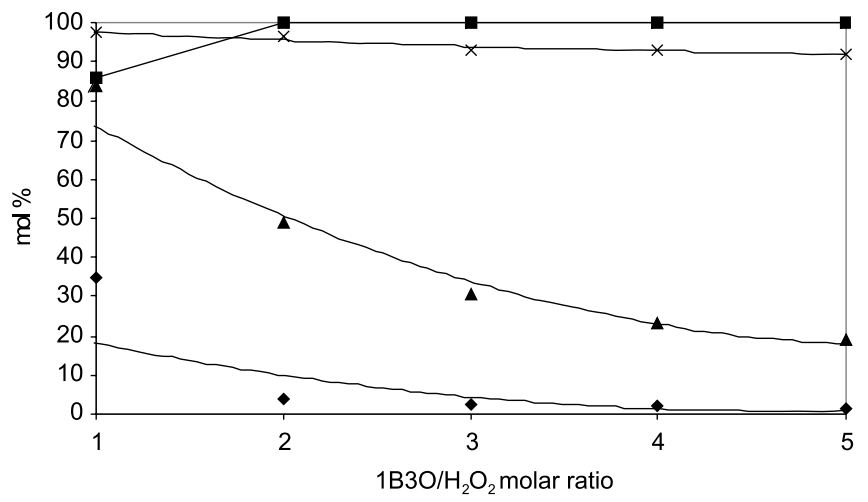

Figure 1. The effect of: a) the temperature on the selectivity of the transformation to 1,2-epoxy-3-butanol in relation to $1 \mathrm{~B} 3 \mathrm{O}$ consumed $(\diamond)$, the selectivity of the transformation to the organic compounds in relation to the consumed $\mathrm{H}_{2} \mathrm{O}_{2}(\boldsymbol{\square})$, the conversion of $1 \mathrm{~B} 3 \mathrm{O}(\boldsymbol{\Lambda})$ and the conversion of $\mathrm{H}_{2} \mathrm{O}_{2}(\mathrm{x})$; b) the molar ratio $1 \mathrm{~B} 3 \mathrm{O} / \mathrm{H}_{2} \mathrm{O}_{2}$ on the selectivity of the transformation to 1,2-epoxy-3-butanol in relation to $1 \mathrm{~B} 3 \mathrm{O}$ consumed $(\checkmark)$, the selectivity of the transformation to the organic compounds in relation to the consumed $\mathrm{H}_{2} \mathrm{O}_{2}(\boldsymbol{\nabla})$, the conversion of $1 \mathrm{~B} 3 \mathrm{O}$ (ム) and the conversion of $\mathrm{H}_{2} \mathrm{O}_{2}(\mathrm{x})$

eters were identical as in the previous series of examinations. From Figure $2 b$ it results that the molar ratio of the reagents considerably affects the selectivity of the transformation of $1 \mathrm{~B} 3 \mathrm{O}$ to $1,2 \mathrm{E} 3 \mathrm{~B}$. The highest selectivity of the transformation to $1,2 \mathrm{E} 3 \mathrm{~B}$ was achieved at the molar ratio $1 \mathrm{~B} 3 \mathrm{O} / \mathrm{H}_{2} \mathrm{O}_{2}=1: 1$. With the increase in the molar ratio over 1 , the main product is formed with less and less selectivity, which is a result of an excess of $1 \mathrm{~B} 3 \mathrm{O}$ in relation to $\mathrm{H}_{2} \mathrm{O}_{2}$. The conversion of $1 \mathrm{~B} 3 \mathrm{O}$ also decreases because of the same reason. The selectivity of the transformation to organic compounds in relation to $\mathrm{H}_{2} \mathrm{O}_{2}$ consumed increases with the increase in the molar ratio of $1 \mathrm{~B} 3 \mathrm{O} / \mathrm{H}_{2} \mathrm{O}_{2}$ from 0.5:1-1:1 (amounts $85.7 \mathrm{~mol} \%$ for the equimolar ratio of the reagents), and for the molar ratio over 1:1 the whole hydroxide peroxide will react effectively. The conversion of $\mathrm{H}_{2} \mathrm{O}_{2}$ is practically constant in the examined range of the parameters and amounts $92.0-98.0 \mathrm{~mol} \%$. On the basis of the studies the molar ratio of $1 \mathrm{~B} 30 / \mathrm{H}_{2} \mathrm{O}_{2}=1: 1$ was considered as the most useful because of the high selectivity of the transformation of $1 \mathrm{~B} 3 \mathrm{O}$ do $1,2 \mathrm{E} 3 \mathrm{~B}(34.8 \mathrm{~mol} \%)$, and also the highest conversion of $1 \mathrm{~B} 3 \mathrm{O}(84.0 \mathrm{~mol} \%)$.

The influence of the solvent concentration (methanol) was examined in the range of $5-90 \mathrm{wt} \%$ and at the 
a)

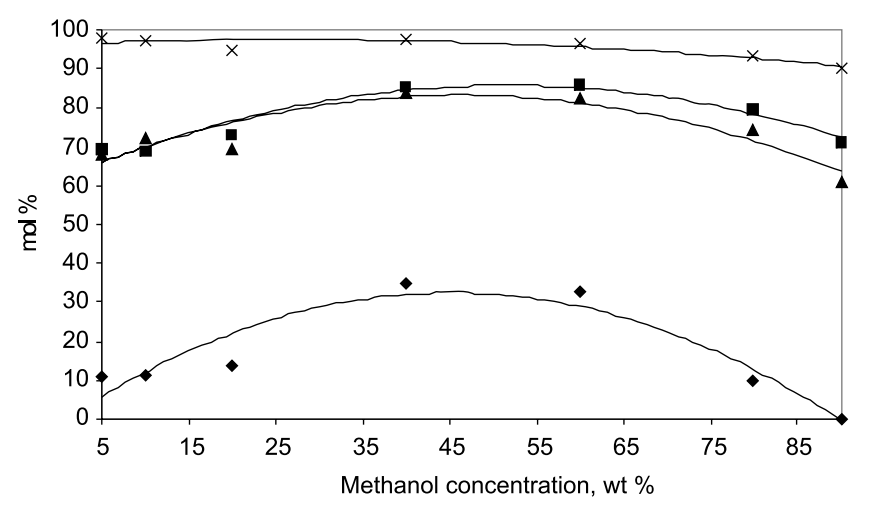

b)

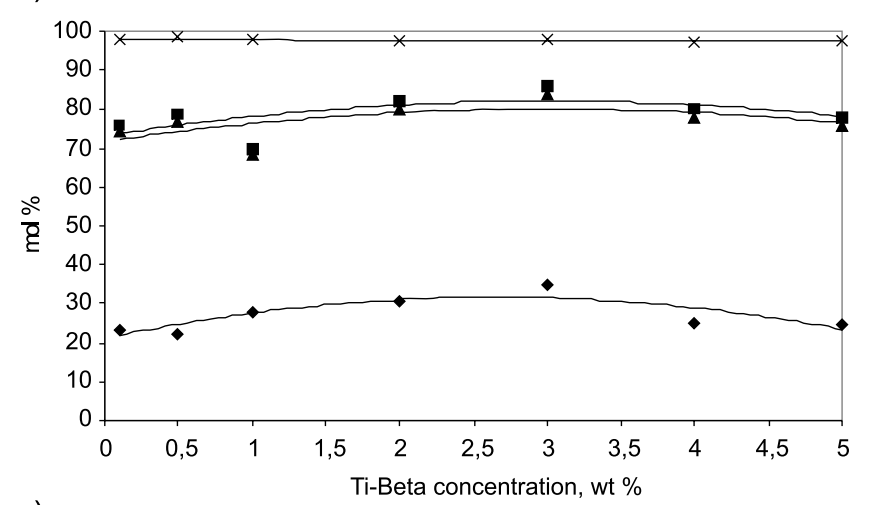

c)

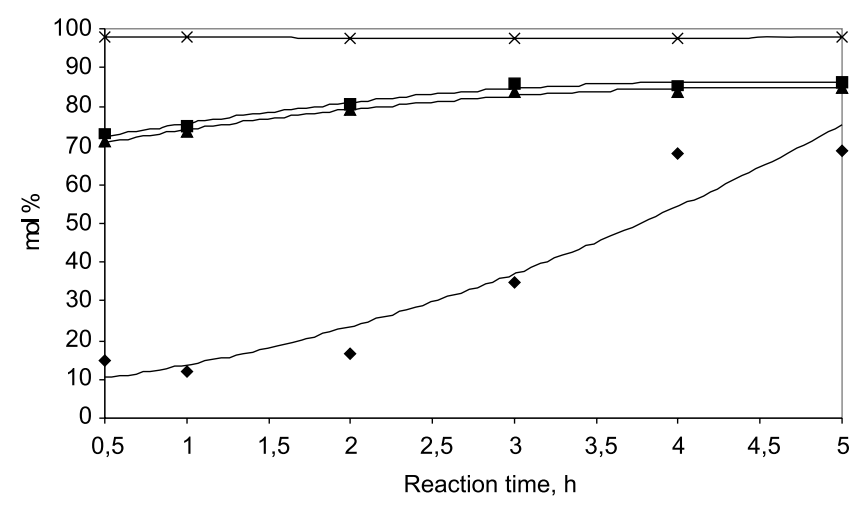

Figure 2. The effect of: a) methanol concentration on the selectivity of the transformation to 1,2-epoxy-3butanol in relation to $1 \mathrm{~B} 3 \mathrm{O}$ consumed ( $)$, the selectivity of the transformation to the organic compounds in relation to the consumed $\mathrm{H}_{2} \mathrm{O}_{2}$ $(\boldsymbol{\square})$, the conversion of $1 \mathrm{~B} 3 \mathrm{O}(\boldsymbol{\Lambda})$ and the conversion of $\mathrm{H}_{2} \mathrm{O}_{2}(\mathrm{x})$; b) the Ti-Beta catalyst concentration on the selectivity of the transformation to 1,2-epoxy-3-butanol in relation to $1 \mathrm{~B} 3 \mathrm{O}$ consumed $(\downarrow)$, the selectivity of the transformation to the organic compounds in relation to consumed $\mathrm{H}_{2} \mathrm{O}_{2}$ $(\boldsymbol{\bullet})$, the conversion of $1 \mathrm{~B} 3 \mathrm{O}(\boldsymbol{\Delta})$ and the conversion of $\mathrm{H}_{2} \mathrm{O}_{2}(\mathrm{x})$; c) the reaction time on the selectivity of the transformation to 1,2-epoxy-3butanol in relation to $1 \mathrm{~B} 3 \mathrm{O}$ consumed ( $)$, the selectivity of the transformation to the organic compounds in relation to the consumed $\mathrm{H}_{2} \mathrm{O}_{2}$ $(\boldsymbol{\square})$, the conversion of $1 \mathrm{~B} 3 \mathrm{O}(\mathbf{\Lambda})$ and the conversion of $\mathrm{H}_{2} \mathrm{O}_{2}$ (x)

temperature of $20^{\circ} \mathrm{C}$ and at the molar ratio of $1 \mathrm{~B} 3 \mathrm{O} /$ $\mathrm{H}_{2} \mathrm{O}_{2}=1: 1$. The rest parameters were identical as the starting ones. From Figure 2a it results that with the increase in methanol concentration from 5 to $40 \mathrm{wt} \%$ the selectivity of the transformation of $1 \mathrm{~B} 3 \mathrm{O}$ to $1,2 \mathrm{E} 3 \mathrm{~B}$ increases from 10.8 to $34.8 \mathrm{~mol} \%$. For the concentrations of methanol over $40 \mathrm{wt} \%$ there is a decrease in the value of the function as far as $0 \mathrm{~mol} \%$ at the concentration of methanol $90 \mathrm{wt} \%$. The conversion of $1 \mathrm{~B} 3 \mathrm{O}$ takes the maximum values at the concentrations of methanol 40 and $60 \mathrm{wt} \%$. The selectivity of the transformation to organic compounds in relation to $\mathrm{H}_{2} \mathrm{O}_{2}$ consumed is at these two concentrations about $86.0 \mathrm{~mol} \%$, which means that almost the whole $\mathrm{H}_{2} \mathrm{O}_{2}$ reacted effectively in the process of $1 \mathrm{~B} 3 \mathrm{O}$ epoxidation. The conversion of $\mathrm{H}_{2} \mathrm{O}_{2}$ is constant in the whole range of the concentrations of methanol and amounts $90.0-98.0 \mathrm{~mol} \%$. According to the received results the concentration of methanol $40 \mathrm{wt} \%$ was considered as the most useful in the epoxidation of 1-buten3-ol.

The studies of the influence of the Ti-Beta catalyst concentration were performed in the range $0.1-5.0 \mathrm{wt} \%$. The highest selectivity of the transformation of 1-buten3-ol to 1,2-epoxy-3-butanol was received at the concentration of Ti-Beta $3.0 \mathrm{wt} \%$ (34.8 mol\%) - Figure $2 \mathrm{~b}$. At the higher concentrations of the catalyst the value of the function slightly decreases to $24.5 \mathrm{~mol} \%$. It probably occurs because the Ti-Beta catalyst at the higher concentrations in the reaction mixture catalyses, also not effective decomposition of $\mathrm{H}_{2} \mathrm{O}_{2}$, in relation with it the epoxidation of $1 \mathrm{~B} 3 \mathrm{O}$ cannot be performed in the same degree as at the lower concentrations of the catalyst. The selectivity of the transformation to the organic compounds in relation to $\mathrm{H}_{2} \mathrm{O}_{2}$ consumed changes slightly in the examined range of the concentrations of the catalyst and amounts about 78.0 $\mathrm{mol} \%$. Almost identically the conversion of $1 \mathrm{~B} 3 \mathrm{O}$ changes and amounts about $76.0 \mathrm{~mol} \%$. The lack of the increase in the values of these two mentioned above functions is probably caused by the decrease in the activity of the catalyst, it can be done by leaching the titanium from the active centers of the catalyst by $\mathrm{H}_{2} \mathrm{O}_{2}$. The conversion of $\mathrm{H}_{2} \mathrm{O}_{2}$ equals about $97.0 \mathrm{~mol} \%$. On the basis of the studies the optimum Ti-Beta catalyst concentration was taken as $3.0 \mathrm{wt} \%$.

The influence of the reaction time on the course of the epoxidation was examined in the range of $0.5-5 \mathrm{~h}$. The other parameters were the same as established as optimal in the previous stages of examinations. The analysis of the changes of the selectivity of the transformation of $1 \mathrm{~B} 3 \mathrm{O}$ to $1,2 \mathrm{E} 3 \mathrm{~B}$ showed that the prolongation of the reaction time from $0.5 \mathrm{~h}$ to $5.0 \mathrm{~h}$ causes the increase in the value of the function from 14.6 to $69.0 \mathrm{~mol} \%$ (Figure 2c). Functions: the conversion of $1 \mathrm{~B} 3 \mathrm{O}$ and the selectivity of the transformation to the organic compounds in relation to $\mathrm{H}_{2} \mathrm{O}_{2}$ consumed take maximum values after 3.0h (the conversion of $1 \mathrm{~B} 3 \mathrm{O} 84.0 \mathrm{~mol} \%$ and the selectivity of the transformation to organic compounds in relation to $\mathrm{H}_{2} \mathrm{O}_{2}$ consumed $85.9 \mathrm{~mol} \%$ ) and then are not practically changed. The conversion of $\mathrm{H}_{2} \mathrm{O}_{2}$ is $98.0 \mathrm{~mol} \%$ in the whole range of the investigated reaction time. After the analyses of the results the time $5 \mathrm{~h}$ was taken as optimum.

\section{CONCLUSIONS}

The optimal parameters of 1-buten-3-ol epoxidation are: temperature $20^{\circ} \mathrm{C}$, the molar ratio of $1 \mathrm{~B} 3 \mathrm{O} / \mathrm{H}_{2} \mathrm{O}_{2}=1: 1$, methanol concentration $40 \mathrm{wt} \%$, the Ti-Beta catalyst concentration $3 \mathrm{wt} \%$, and the reaction time of $5 \mathrm{~h}$. Under 
these conditions the selectivity of the transformation to 1,2-epoxy-3-butanol in relation to 1-buten-3-ol consumed equals $69.0 \mathrm{~mol} \%$, the selectivity of the transformation to organic compounds in relation to 1-buten-3-ol consumed $86.4 \mathrm{~mol} \%$, and the conversion of a 1-buten-3-ol 85.1 $\mathrm{mol} \%$. The fact that the great amount of hydrogen peroxide, which reacts in the process, is effectively transformed into the organic compounds should be considered. From the point of view of the separation of products by distillation after the process, the high conversion of the hydrogen peroxide $(98,0 \% \mathrm{~mol})$ is useful because we do not need to decompose hydrogen peroxide before distillation.

\section{ACKNOWLEDDEMENT}

The research was funded by project No. R05 01901 of the State Committee for Scientific Research (KBN).

\section{LITERATURE CITED}

(1) Pielichowski J., Łukasiewicz M.: Nadtlenek wodoru w nowoczesnych procesach technologii organicznej, Przem. Chem., 2002, 81(8), 509.

(2) Milchert E., Tarachowicz L.: Synteza i zastosowania katalizatora tytanowo-silikalitowego, Chemik, 1995, 9, 251.

(3) van der Waal J. C., Rigutto M. S., Van Bekkum H.: Zeolite titanium beta catalyst as a selective catalyst in the epoxidation of bulky alkenes, Appl. Catal. A: General, 1998, $167,331$.

(4) Valluri M., Hindupur R. M., Bijoy P., Labadie G., Avery M. A.: Total synthesis of epothilone B, Org. Lett. 2001, 23, 3607.

(5) Hindupur R. M., Panicker B., Valluri M., Avery M. A.: Total synthesis of epothilone A, Tetrahed. Lett., 2001, 42, 7341.

(6) Kąkol B., Jegierska-Zięba M., Kamieński J., Bełdowicz M., Szpakiewicz M., Soliński J.: Chlorowodorek (2R, 3S)fenyloizoseryny jako półprodukt do otrzymywania Paclitaxelu, Przem. Chem., 2002, 81, 780.

(7) Hatakeyama S., Samurai K., Takano S.: Preparation of o-protected (2S,3S)-1,2-epoxy-3-butanols. Enantioselective syntheses of (-)-rhodinose and (+)-epimuscarine iodide, Heterocycles, 1986, 24, 633.

(8) Camblor M. A., Corma A., Martinez A., Perez-Pariente J.: Synthesis of a titaniumsilicoaluminate isomorphous to zeolite beta and its application as a catalyst for the selective oxidation of large organic molecules, J. Chem. Soc., 1992, 8, 589.

(9) Brill W. F.: The origin of epoxides in the liquid phase oxidation of olefins with molecular oxygen, J. Am. Chem. Soc., 1963, 85, 141. 